\title{
EVOLUTION AND REVOLUTION IN SCHOOL LIBRARY PRACTICE ${ }^{2}$
}

\author{
Suzette Boyd \\ Director of Library Services \\ Methodist Ladies' College \\ 207 Barkers Road \\ Kew, 3101, Victoria Australia \\ Email: boyds@mclkew.edu.au
}

\begin{abstract}
What future are we as teacher-librarians doing to respond to...or choose for ourselves? Will it be the safe, well-worn "evolutionary" highway on which the majority of school libraries are moving, or will it be the exciting and challenging "revolutionary" path with its associated risks? The revolutionary library signals a new era for schools and their students. Here roles are continually being redefined and services and programs are continually restructure. This paper outlines some strategies for implementing change and challenges and inspires our profession to reinvent itself.

\section{WHY DO WE NEED A REVOLUTION IN THE WAY THE TEACHER-LIBRARIAN OPERATES?}

Against a background of the information revolution, in which the amount of information available on any given subject is increasing at an exponential rate; a paradigm shift in pedagogy from teaching students to helping students learn; and information technology making possible unlimited access to information on the Internet, our professional world has changed dramatically in recent years. We now see students accessing whatever they want on the World Wide Web and communicating by e-mail with experts around the globe often without input from their teachers. Information literacy skills will include skills that teachers do not have and have not taught their students. Our expertise in this area is needed more than ever.

What future are we as teacher-librarians going to respond to...or choose for ourselves?

\section{THE CURRENT SITUATION IN SCHOOL LIBRARIES} attitudes:

At the present time in school libraries there seem to be three prevailing general scenarios or

1. Doom and gloom. This is the worst scenario. Teacher-librarians in this scenario have the underlying attitude that it has all become too hard. They resent the constant demands for change placed upon them by computerized library systems and information technology in a time of costcutting; they resent the lack of support in the school for their role, and they are unable to see past the negatives. In their schools the school administration has responded by putting the CD-ROM network and the Internet developments in the hands of the information technologists rather than with the information service professionals. Let us hope these doom-and-gloom teacher-librarians are in the minority.

2. Evolutionary. A large proportion of school libraries are in an "evolutionary" state at the moment. The teacher-librarians in this scenario have the underlying attitude of comfort with the status quo. These teacher-librarians:

- focus on the daily routine, rather than long-term planning and goal-setting

${ }^{2}$ In February 1997 this paper appeared under the title of Choosing a revolution: The role of the information service professional into the 21st century in SCAN 16(1) 
- have a wait-and-see attitude

- usually have a comfortable profile

- will have some resistance to change amongst their staff

- will implement new services, but will engage in little or no risk-taking

- have a cautionary approach

- can become complacent

- do not acknowledge that paradigm shifts are possible in their organization.

3. Revolutionary. The underlying attitude of the group of teacher-librarians in this scenario is: "this is a new era for libraries with many schools doing wonderful things." Revolutionary libraries and teacher-librarians:

- have shared decisions and a shared vision

- think big and take risks

- are strong leaders

- have a clear mission statement and clearly defined goals

- focus on mission critical practices

- practice "Total Quality Management" which in a library means total quality service

- encourage all staff to develop expertise and a profile

- are continually redefining roles

- provide varied opportunities for staff training and development

- value and reward competencies, not degrees - they foster the concept of a learning organization

- reengineer traditional library practices

- compete successfully for resources within the parent organization

- are used for bench-marking by other school libraries....and

- choose their own future. This is the fundamental difference between evolutionary and revolutionary teacher-librarians.

\section{ACHIEVING REVOLUTION AT METHODIST LADIES' COLLEGE}

When I was appointed to Methodist Ladies' College (MLC) in 1993, my brief was to take The Walton Library into the 21st century. Some heady strategic planning was obviously in order. MLC is a day and boarding school for over 2200 students from kindergarten to Year 12. The educational philosophy of the school is one that encourages active, self-directed learning, where students and teachers are learning together. The library needed to be brought into line with this philosophy. It was not user-friendly, had some casual, uncommitted and unqualified staff, and had a negative profile which is worse than no profile.

In my position as Director of Library Services I believe in:

- The significance and importance of my role as a teacher-librarian;

- Student-centered independent learning;

- Being people focused and service-centered;

- Always looking for a different way of doing things;

- The power of positiveness;

- My staff and their professional development;

- Having and sharing a vision and having clearly defined goals (because those who do not have goals will be controlled by those who do);

- Results and productivity.

\section{STEPS TO REVOLUTION}

The revolutionary process began in 1993 with:

- The employment of professional staff and redefining the roles of those staff who wanted to stay on and be part of the change;

- The development of a mission statement;" The Walton Library exists to provide a dynamic environment for independent learners, with services and curriculum resources of 
the highest quality and relevance. It embraces technological change and the promotion of reading and is a leader in Independent School Libraries in Australia."

- Establishing user-friendly systems;

- Provision of student focused services and a friendly vibrant atmosphere;

- Physical reorganization of all spaces;

- Technology upgrade - the library was now linked to the school network for the first time;

- Getting rid of practices that did not support the mission;

- Marketing, marketing, marketing.

The revolutionary process continued in 1994 as we:

- Established small teams for the functioning of the library. Each team developed an aim and objectives and wrote action plans for each objective;

- Installed a CD-ROM network;

- Established international links for acquisition;

- Focused on new user services and educational initiatives (such as new student cards, selfcheck, security system, Information Skills Program, Literature Club, Friends of the Library, Library Expo, Literary Dinner, and Professional Development programs for teaching staff).

1994 was the big year for substance and a real enhancement of profile.

In 1995, we:

- Began the reengineering process with outsourcing of cataloguing, resulting in the chance for teacher-librarians to develop new and revolutionary programs;

- Initiated Visitor's Days. Other schools and libraries were by now calling regularly for information about our programs, so we instituted a visitor's program;

- Conducted seminars on the Internet for parents;

- Offered an Information Networker course for students at lunchtimes and after school.

- Became a professional development provider for teachers. Courses are offered to teachers in search strategies; advanced searching of the library catalogue; using search engines; Home Page development; using e-mail; incorporating the Internet into the curriculum and other professional development as requested;

- Expanded our networked information services with e-mail, Internet access, further development of CD-ROMs and online ordering.

In 1996 the following initiatives were possible because of the decision to out source our cataloguing:

- Production and sale of CD-ROM User Guides;

- Community Access. We opened our doors to members of the public until 9.00 p.m. four nights a week and charged a AUS\$60 subscription for 10 weeks. This subscription included unlimited access to the Internet;

- Development of Library Home Page, accessible at http://www.mlckew.edu.au/library/. It contains information on resources and programs offered by the library; a page of hypertext links to education, reference, world news, literature and cool sites. Our home page is maintained by the library staff;

- Start of Information Access program via electronic pathfinder;

- SEARCH pages on the Intranet to assist students using Netscape search engines.

\section{THE CHALLENGE: CHOOSING OUR FUTURE}

We cannot expect that others will automatically think our profession is vital and provide resources and support-we have to make our leaders believe that we are the "star resource of the school" (as I heard the teacher-librarian described last year at the Learning Environment Technology Australia conference in Adelaide). At this same conference, the 21st century was described as the competitive century, where creativity, individuality and risk-taking will be the most highly valued characteristics of an employee. The challenge is to decide if we want to take 
the risk of choosing our own future. If we take up this challenge we will need:

- A leader (library director) with the following characteristics: knows his/her own strengths and weaknesses; is good at judging others' abilities; is a good teacher; delegates; can handle it when people dislike him/ her; can share credit and blame equally.

- Library staff (and all teams) with the following personality types: an intuitive to offer ideas and to spot trends; a thinker to carry out procedures and to get things done; a sensitive to provide a sounding board.

We also need to be asking ourselves and our staff:

- What are we doing?

- What should we be doing?

- What should we be doing next?

- What should we not be doing.

We will also need:

- to build credibility by identifying areas of support from within the school; to encourage staff who are committed team members, rather than having the attitude "I just work here";

- to encourage experimentation and risk-taking;

- to build skills across all staff;

- to have a set of beliefs that are identifiable in the form of a mission statement and that are compatible with the mission of the parent organization;

- to value human resources and not allow technology to rule;

- to improve performance through the use of technology;

- to think and act entrepreneurially;

- to market ourselves and our library;

- to be accountable and continuously evaluate our role and performance;

- to be prepared to throw off the old if it is no longer mission critical;

- to aim for and expect the best performance from ourselves and our staff

- to make decisions with "the big picture" in mind...and let's not exhaust ourselves with trivial change!!! 